\title{
Renal cell cancer with solitary gastric metastasis: a rare presentation
}

\author{
Kalpesh Parmar (10 , Abhishek Chaube, Santosh Kumar, Murali Krishna
}

Urology, Post Graduate Institute of Medical Education and Research, Chandigarh, India

\section{Correspondence to} Dr Kalpesh Parmar; kalpesh010385@gmail.com

Accepted 24 May 2021

\section{DESCRIPTION}

A 65-year-old man, known case of coronary artery disease on dual antiplatelet therapy, presented in emergency with two episodes of sudden onset haematemesis. There was no history of melena, altered bowel habits, flank pain, jaundice, generalised lymphadenopathy or bleeding tendencies in the past. On further evaluation, the patient reported undocumented weight loss in the past 3 months. His medical and family history was insignificant. On examination, the patient was conscious, oriented and his vitals were stable. Systemic examination was grossly normal. Routine blood investigations showed haemoglobin $84 \mathrm{~g} / \mathrm{L}$, serum creatinine $0.7 \mathrm{mg} / \mathrm{dL}$, and liver functions and urine analysis were within normal limits. The patient was transfused two units of packed red blood cells and started on injectable antacids. Contrast-enhanced CT showed a solitary $8 \times 10$ $\mathrm{cm}$ exophytic enhancing heterogeneous mass in the upper and mid pole of the right kidney with a solitary space occupying lesion (SOL) in the fundus of the stomach (figures 1 and 2). There was no evidence of regional lymphadenopathy or distant metastasis. Chest X-ray was grossly

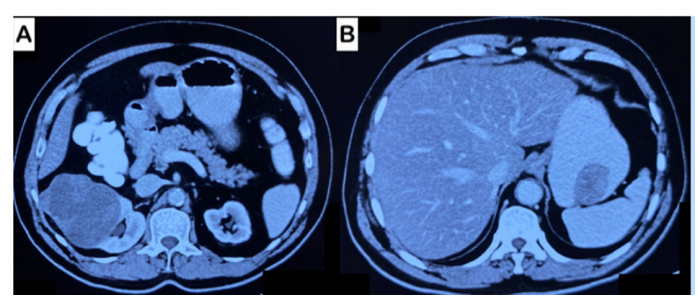

Figure 1 (A) Contrast-enhanced CT axial image showing exophytic heterogeneous enhancing mass in the upper and mid pole of the right kidney. (B) Image showing a well-defined enhancing mass with smooth outline in the gastric fundus.

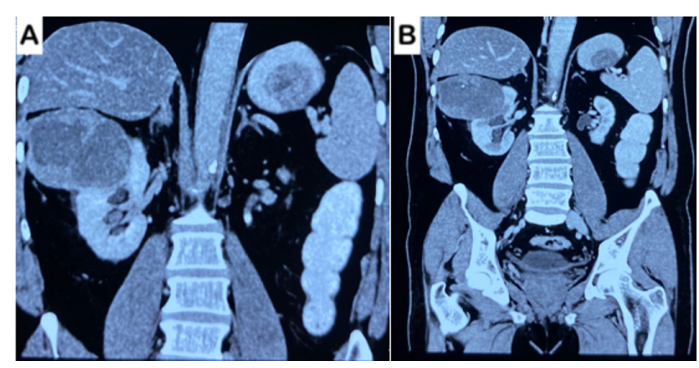

Figure 2 ( $A, B)$ Contrast-enhanced $C T$ coronal image showing heterogeneous $8 \times 10 \mathrm{~cm}$ enhancing mass in the right kidney with areas of internal necrosis and a welldefined enhancing mass in the gastric fundus.

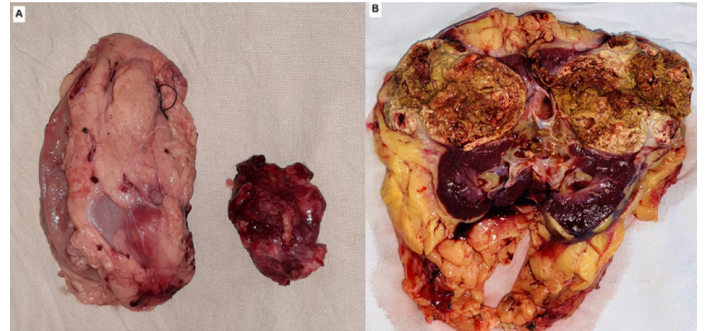

Figure 3 (A) Gross specimen of right cytoreductive nephrectomy and gastric metastectomy. (B) Cut specimen of right cytoreductive nephrectomy showing variegated yellowish mass in the upper and mid pole of the kidney with areas of necrosis.

normal. Gastroenterology opinion was taken. Upper gastrointestinal endoscopy showed a welldefined submucosal lesion in the gastric fundus. The biopsy of the gastric lesion showed metastatic clear cell cancer. In view of solitary gastric metastasis with right renal cell cancer (RCC), the patient underwent right radical nephrectomy with gastric SOL excision. Cut specimen showed variegated solitary growth in the upper and mid pole of right kidney (figure 3). Postoperative hospital stay was uneventful. Histopathology confirmed International Society of Urological Pathology grade 2 clear cell renal cancer with similar histology in the gastric lesion (figure 4). The patient was started on tablet pazopanib $400 \mathrm{mg}$ two times per day on follow-up. At 1 year, the patient is doing well.

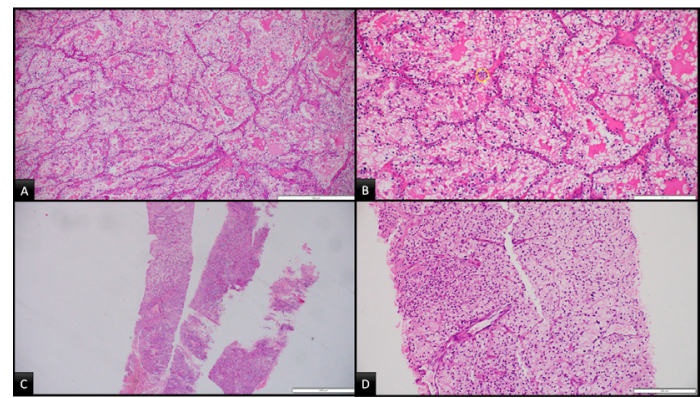

Figure 4 Panel of microphotographs showing $(A)$ renal tumour with cells arranged in nests and alveoli separated by fine capillary network. Areas of cystic change is also seen (H\&E, 100× magnification). (B) The tumour cells have abundant clear cytoplasm and mildly pleomorphic nuclei with conspicuous nucleoli at 200x magnification (International Society of Urological Pathology grade 2). (C) Histology from the stomach lesion showing metastatic deposits. (D) The tumour cells also show clear cell morphology. 
There is no evidence of recurrence on fluorodeoxyglucose positron emission tomography scan, and liver and renal functions are within normal limits. Haematemesis is the rarest presentation of RCC. ${ }^{1}$ RCC with synchronous solitary metastasis to the stomach is extremely rare. $^{2}$ Little is known regarding the biological mechanism that drives RCC metastasis. ${ }^{3}$ The proposed hypotheses are tumor-derived microvesicles (which essentially break off from the primary site) which may disperse tumours through haematogenous routes. ${ }^{4}$ In good-risk patients of RCC with oligometastatic disease, excision of the lesion with cytoreductive nephrectomy has shown favourable response. In

\section{Patient's perspective}

I am extremely thankful to the whole team of doctors for taking care of me during my treatment and hospital stay.

\section{Learning points}

- Renal cell cancer (RCC) with solitary gastric metastasis is rare.

- Haematemesis is an unique presenting feature of metastatic RCC.

- Cytoreductive nephrectomy with solitary gastric space occupying lesion excision, if feasible, should be performed. the index case, the patient underwent radical nephrectomy with gastric SOL excision and is doing well on follow-up.

However, long-term follow-up is required to know any conclusive evidence on survival. ${ }^{5}$

Contributors KMP and AC: Manuscript design, concept, data collection and drafting. MK: Images editing. SK: Critical comments.

Funding The authors have not declared a specific grant for this research from any funding agency in the public, commercial or not-for-profit sectors.

Competing interests None declared.

Patient consent for publication Obtained.

Provenance and peer review Not commissioned; externally peer-reviewed.

\section{ORCID iD}

Kalpesh Parmar http://orcid.org/0000-0003-3891-4089

\section{REFERENCES}

1 Pal SK, Choueiri TK, Karam JA, et al. Metastatic renal cell carcinoma: Contending with a sea change in therapy. Urol Oncol 2015;33:507-8.

2 Pal SK, Figlin RA. Targeted therapies for renal cell carcinoma: understanding their impact on survival. Target Oncol 2010;5:131-8.

3 Callea M, Albiges L, Gupta M, et al. Differential expression of PD-L1 between primary and metastatic sites in clear-cell renal cell carcinoma. Cancer Immunol Res 2015:3:1158-64.

4 Grange C, Tapparo M, Collino F, et al. Microvesicles released from human renal cancer stem cells stimulate angiogenesis and formation of lung premetastatic niche. Cancer Res 2011;71:5346-56.

5 Eggener SE, Yossepowitch O, Kundu S, et al. Risk score and metastasectomy independently impact prognosis of patients with recurrent renal cell carcinoma. J Urol 2008;180:873-8.

Copyright 2021 BMJ Publishing Group. All rights reserved. For permission to reuse any of this content visit https://www.bmj.com/company/products-services/rights-and-licensing/permissions/

BMJ Case Report Fellows may re-use this article for personal use and teaching without any further permission.

Become a Fellow of BMJ Case Reports today and you can:

- Submit as many cases as you like

- Enjoy fast sympathetic peer review and rapid publication of accepted articles

- Access all the published articles

Re-use any of the published material for personal use and teaching without further permission

\section{Customer Service}

If you have any further queries about your subscription, please contact our customer services team on +44 (0) 2071111105 or via email at support@bmj.com.

Visit casereports.bmj.com for more articles like this and to become a Fellow 